sity of Cambridge, for her work on the physiology of the sense of time and the basis of periodic activities in lower animals. The Stamford Raffles Award, to Mr. C. W. Mackworth-Praed, of Castle Top, Burley, Hampshire, in recognition of his distinguished contributions as an amateur zoologist to omithology. The award is a bronze sculpturo by Mr. Henry Moore. The Thomas Henry Huxley Award, to Dr. C. H. O'Neill, of King's College, for original work submitted as a doctor's thesis to the University of London, on the "isolation and some properties of the cell surface membrano of Amoeba proteus". The award is a bronze sculpture by Mr. Henry Moore. A Certificate of Commendation has also been awarded to Dr. L. Hill, of the Department of Zoology, University of Sheffield, for his thesis on "Endocrine Control of Oocyte Development in the Desert Locust Schistocerca gregaria". The Prince Philip Prize (open for compotition to pupils of zoology taking the General Certificate of Education Advanced-level Examination or equivalent), to Janice Cornell (aged nineteen years), of the County Grammar School for Girls, Potters Lane, Lewes, Sussex, for her entry, "The Relationship between Light Intensity and Temperature on the Horizontal Velocity of Polycelis nigra (Ehrenberg)". The award is a bronze sculpture by Mr. Henry Moore. The Society's Bronze Medal, to Mr. G. J. Ashby, overseer of the Aquarium and Invertebrates of the London Zoo, and Mr. F. J. Myers, Clerk of Works at the London Zoo, for their distinguished and devoted servicos.

\section{Oxidation of Reduced Triphosphopyridine Nucleotide of Guinea Pig Polymorphonuclear Leucocytes}

IN the communication under the above title by Prof. J. H. Quastel and Dr. J. Roberts, which appeared on p. 85 of the April 4 issue of Nature, line 11 of the second paragraph should read "The catalytic properties of erystalline horse-radish peroxidase on NADPH oxidation were similar to those of the leucocyte oxidase". Furthermore, the reaction sequence depicted in paragraph six should be:

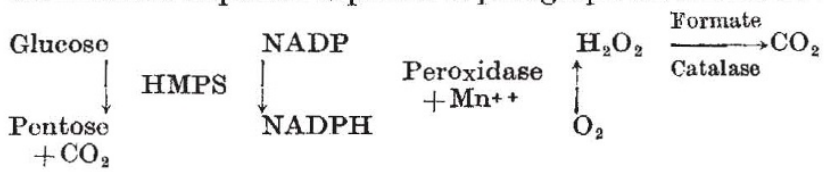

\section{The Selby Fellowship}

The Selby fellowship has been established by the Australian Academy of Science to bring graduates of high promise and provod capacity for research to work in the laboratories of universities or research institutions in Australia. The followship may be awarded in any branch of physical or biological science, and is tenable at any university or research institution in Australia, normally for one full year of work. Candidates must have taken their first university degree, and have had preliminary research experience, at some university or universities in a country other than Australia. Each applicant should (unless some special considerations are advanced) be less than thirty years of age on July 1 in the year in which his application is recoived. Applicants should, in general, hold a Ph.D. degree or have equivalent status and experience, but the fellowship will not normally be given to those who have already held a senior research award. The Selby fellowship will carry a stipend of $£ 2,000$ (Australian) per annum. The costs of the Fellow's travel to Australia and back to his country of origin at the conclusion of the fellowship will be provided, up to a limit of £A500, including dependants, if any. Where it is essential for the prosecution of the work carried out during the tenure of the fellowship, a limited sum may be allocated for travel within Australia. Each applicant is required to state the general nature and scope of the research that he wishes to undertake, and the university department or research institution in which he seeks to work. Appli- cations should be sent by July 30 to the Assistant Secretary, Gordon Street, Canberra City, A.C.T., from whom further information can be obtained.

\section{Announcements}

Mr. H. H. Gardner, technical director, British Aircraft Corporation (Weybridge), Ltd., has been elected president of the Royal Aeronautical Society for 1964-65. Mr. Gardner succeeds Prof. A. R. Collar.

Mr. F. S. Sellars, assistant general manager, Refineries Department of the British Petroleum Company, London. has bcen elected president of the Institution of Chemical Engineers for the session 1964-65. Formerly, Mr. Sellars was professor of chemical engineering in the University of Wales, at University College, Swansea.

The annual meeting of holders of Nobel Prizes will be held in Lindau during June 22-26. Further information can be obtained from the Sekretariat der Tagungen dex Nobelpreisträger, 899 Lindau (Bodensee), Postfach 11.

THE inaugural meeting of the Society for Develop. mental Biology will be held in Oxford on June 20. Further information can be obtained from Dr. J. B. Gurdon, Zoology Department, Univorsity Museum, Oxford.

AN international conference on "The Physics and Chemistry of Solid Surfaces" will be held at Brown University, Rhode Island, during June 21-26. Further information can be obtained from Prof. H. E. Farnsworth, Brown University, Providence, Rhode Island.

THE summer courses of the Enrico Fermi International School of Physics, organized by the Societa Italiana di Fisica, will be held at Varenna. Three courses will be held as follows: weak interactions and high-energy neutrino physics (June 15-27); strong interactions (July 6-18); molecular biophysics (July 23-August 18). Further information can be obtained from Prof. G. Germana, Società Italiana di Fisica, Via Irnerio 46. Bologna.

THE first international conference of women engineers on "Focus for the Future-Developing Engineering and Scientific Talent", sponsored by tho Society of Women Engineers, will be held in New York City during June 15-21. The Caroline Haslett Memorial Trust is offering a bursary of $£ 250$ to help one or two women engineers to meet the expense of attending the conference. Further information can be obtained from Mrs. Isabel Hardwich. Power Group Research Laboratory, Associated Flectrical Industries, Trafford Park, Manchester 17.

THE forty-seventh annual conference of the Chemical Institute of Canada will be held in Kingston, Ontario. during June 1-3. During the conference, the Merck, Sharp and Dohme lecture, entitled "Studies on Soluble Ribonueleic Acids", will be delivered by Dr. G. Tener of the University of British Columbia. Further informa. tion can be obtained from the Chemical Institute of Canada, 48 Rideau Street, Ottawa 2, Ontario.

Errata. The address of the Association of the British Pharmaceutical Industry is now Mercury House, 195 Knightsbridge, London, S.W.7, and not B.M.A. House, Tavistock Square, London, W.C.1, as givon in the article "Research Expenditure in the Pharmaceutical Industry", which appeared on p. 140 of the April 11 issue of Nature.

In the article entitled "A Simple Alternative to the Antoine Fxpression for Relating Gas Chromatographic Retention Data and Temperature", by M. B. Evans and J. F. Smith, which appeared on p. 1281 of the March 28 issue of Nature, line 8 from the bottom of the left-hand column on p. 1282 should read, "Higher terms, such as $\tau\left(T-T_{1}\right)^{3}$, do not . . ". 